\title{
OPINIONS REGARDING THE FUNDAMENTAL DOMAINS OF NATIONAL SECURITY
}

\author{
Gheorghe UDEANU \\ “Nicolae Bălcescu” Land Forces Academy, Sibiu, Romania \\ udeanu@armyacademy.ro
}

\begin{abstract}
The multiple dimension of national security in the international contemporary contextcharacterized by accelerated, radical changes - is determined by the necessity of constantly promoting and permanently defending our national values and interests against the extraordinary diversity of insecurity factors - destabilizing vectors that manifest themselves in a surprising manner and create difficulties in the process of assessment of the specific disruptive effects. This complex framework of social evolution offers numerous perspectives for the analysis of the concept of security, but these studies do not need to dilute its fundamental connotations, but it is necessary for these efforts to particularly relate to the subsystems that are really relevant for individual and collective security and maintenance and, on the basis of a very good documentation, be exactly circumscribed into the legislative coordinates that correspond to the reference domain. " [1]
\end{abstract}

Keywords: national security, protection of critical infrastructure, civil protection, public order, constitutional order, national defence, national security, assumed risk, societal vulnerabilities.

\section{Introduction}

The concept referring to security is frequently employed in contemporary usage, but the diversity of perceptions regarding the sphere of influence and integration of its reference domain has configured the existence of different analytical perspectives and not allowed for the possibility of promoting a unanimously accepted definition.

"This multitude of investigating options does not at all reflect the fact that people are not aware of the fundamental role of security in providing feelings of peace and confidence in the future of humanity, but rather expresses the full attention and multiple concern paid to determining all the factors of individual and collective insecurity, as well as to promoting organizational and functional sets of measures necessary to prevent or annihilate their negative effects on the balance of social systems" [2].

\section{Factors of insecurity - risks, defiances, challenges, dangers, threats and aggressions. The amplifying influence of societal vulnerabilities on their negative effects}

In the contemporary context of the evolution of international society, the accelerated development of global informational, political, economic, financial networks or of any other nature is simultaneously associated with a process of amplification of the structural vulnerabilities [3] of these social complex sets, caused by the strong influence of the diversity of defiances [4], challenges [5], dangers [6], threats [7] and aggressions [8] that can seriously affect the organizational and functional protection and stability, producing effects with negative consequences at a planetary level. The 
described framework certainly requires continuous taking risks [9] in the decisionmaking process meant to re-configure these macro systems and permanently adapt them to the new environment conditions.

"Risk represents the possibility that the structure of a social system can be affected to the extent of shutdown, if the decision makers do not adopt a proper attitude required for reducing or annihilating some possible perilous effects determined by defiance, challenge, danger, threat or aggression against its existence" [10].

Thus, the risk is consciously assumed, being imposed to a decision or associated with it as a collateral random, unexpected and initially unconscious factor. "There are no rules for assessing risk, as there are no rules for the choice of a good solution; risk assessment is a matter of intelligence, but also of knowledge and experience." [11]

"Being a complex set of judgments, analyses and syntheses, directly influencing the decision making, its character is obviously subjective. Risk-taking requires rigor and accuracy in the evaluation of possible influences of defiances, challenges, dangers, threats and aggressions on the social system being run and, in this regard, the specialized literature suggests several matrices to quantify their scientific determinations.

Although contemporary society generally evolves towards prosperity and comfort, there are many areas characterized by extreme poverty, which increases the range of socio-economic crises. These major imbalances are caused by the unwise distribution of resources and results of human activity. Consequently, the insecurity factors - the defiances, challenges, dangers, threats and aggressions specific to the contemporary world - influence any decisional act, determining risk-taking, but they act with the greatest intensity in the management of the state power structures during the actions meant to restore public and constitutional order and, particularly, in the context of an armed conflict or war, becoming major risk factors.
In the process of political, political-military decision-making process of high responsibility, it is necessary that the risk factors should be analyzed from the perspective of the amplified intensity of their negative influence over the state and its power structures - defiances, challenges, dangers, threats and aggressions - on the basis of criteria allowing to most accurately determine their characteristics, so as to select and classify them, eliminating any confusion in terminology. This analytical logic ensures setting the level of risk assumed with a high degree of certainty and gives the opportunity to unitarily coordinate the activities designed to maintain consistency in the organizational and functional flows within the macro state and armed forces systems" [12] .

In the existential contemporary context, amplifying the effects of insecurity factors is the result of both the decisional risk assumed and the vulnerabilities of societal systems. Identifying the vulnerabilities and their multiplying effects on the factors generating crises is an extremely complex analytical process, but absolutely necessary for an effective security management.

"The difficulty of this study is given by the phenomenon of globalization that influences the structure and internal relations of any social system, causing their frequent shaping and reshaping due to the need to maintain its connection to a broad and deep information network of ultra specialized forecasting, planning, organization, coordination and execution. The numerous modifications having an adaptive purpose may affect the efficient functioning of the system because the time allotted for a detailed analysis of the risk taken is insufficient and thus its vulnerabilities go entirely unnoticed, which enhances the possibility of their manifestation in a surprising manner.

The vulnerabilities of a social system are made present and disseminate their negative influences as a result of the mismatch between the purpose, objective or its core mission and the real potential of the component subsystems, resulting in even 
major imbalances and functional deficiencies, including the ones on the systems with which it interacts.

Consequently, the weaknesses of any social and human organization are internal and have two major causes: inadequate structure and dysfunctions of the component subsystems.

At the level of national security system, the vulnerabilities are consequences of the inadequate formation of its structure, in disagreement with the real evolution of the state, which determines the faulty functional processes of the component subsystems, reducing the preventive potential and producing the ineffective response when crises appear and proliferate" [13].

\section{Terrorism -principal source of social instability}

"Terrorism constitutes one of the most serious existential situations of modern society, expressed by intolerance, violence, destructiveness, extremism and absurd direct attacks on human life, taking place indiscriminately and without any moral and legal norms. Through its imagologic and psychological effects propagated sometimes on a global scale, it has a direct influence over the individual and collective safety, causing high consumption of resources and specialized forces for prevention and deterrence" [14].

The gravity of contemporary terrorism is given by the diversity and complexity of the specific networks, the surprising nature of terrorist acts and the major psychological effects.

"The causes of terrorism are complex, and their genesis is determined by the dynamics and diversity of political, economic, cultural, social and even military crises. The terrorist phenomenon is extremely dangerous, focusing on violent religious extremism and political extremism manifested by unpredictable actions carried out in urban areas, public places and institutions in the context of which, without discernment, with fast and extreme violence, generalized panic and terror are caused by the direct attack on life, most often on absolutely innocent beings.

Terrorism is not, as sometimes they try to justify it, a reaction of the weak against the strong, but a premeditated punitive and vindictive, inhuman, criminal action - often suicidal and always fierce - which aims to destroy, to cruelly kill and frighten. Terrorism is not justified and cannot be justified in any way, since it does not appear either as a way to unlock a strategic situation - as war is shown in general - or simply as a reaction of revenge against an enemy that you cannot hit otherwise, but as an unexpected and criminal aggression against the human being, civilization and systems of values" [15].

In the specialized analytical environments, the terrorist defiances, challenges, dangers, threats and attacks are estimated to be the most difficult to understand, accept and manage after the ones represented by the existence, proliferation and the possibility of using weapons of mass destruction. There is a clear tendency for terrorism to expand in all spheres of social activity and to have in view the destruction of the character of efficiency and progress of mankind.

"The main sources of generation of terrorism can be found in the diverse array of contemporary society and tremendous diversity of spheres of interest and influence of states and transnational companies:

- the unpredictable, contradictory and conflict-generating effects of the process of globalization, laid over the regionalization process and the trend of state de-structuring;

- the huge technological gap between the Western societies and the rest of the world, causing the accumulation of particularly economic and financial values in confined spaces, while amplifying the phenomenon of poverty in larger and larger areas;

- the impossibility of circumscribing terrorist acts in consecrated unanimously accepted legal terms, with the view of condemning and stopping this phenomenon; 
- the use of uncontrollable financial resources for the preparation and conduct of terrorist actions resulting from illicit trafficking in drugs, arms and people;

- the presence of large masses of young Muslims in the Western societies and the enhance of their existential state of uncertainty and despair caused by the major difficulties to integrate into the socioeconomic activities;

- the awareness of the deeply impoverished societies, that are on the borderline of existential threshold, of the fact that their national territories have rich natural resources, which are clearly and defiantly capitalized, to the detriment of their own nations" [16].

"The sources generating terrorism are directly proportional to the overall evolution of human society. In this sense, the more spectacular the technological advances in the highly developed areas are, producing a steady growth in the high comfort and standard of living, the greater the disproportion between these societies and the areas of extreme poverty and the lack of minimum conditions of existence" [17]. This contradiction amplifies the feelings of frustration, injustice, despair and abandonment of large masses of people who are easily manipulated in the name of ideals regarding justice, equity and truth. In this context, the possibility of selecting and training people prone to the ultimate sacrifice through actions without any discrimination, with incalculable consequences is increased.

"Contemporary terrorism - system, networking, fault, mosaic etc. - is mainly directed against the overdeveloped societies, and the areas generating and regenerating groups, organizations and networks cross borders and have numerous channels. The recruitment base is the young population that lives feelings of dissatisfaction and deep discrimination, easily embracing extremistfundamentalist concepts, characterized by deep contempt for life and promotion of the ultimate sacrifice as a result of the cultivation of dogmas perceived as indisputable, supreme truths, involving revenge by extreme violence" [18].

\section{Fundamental domains of national security}

"The studies on the concept of security have multiplied in recent years, so that out of the original concept numerous derivatives have been promoted: national security, zonal, regional, continental, international, common, democratic, political, informational, technological, military, economic , financial, critical infrastructure, energetic, of strategic resources, social, public, human, individual, community, food, environmental, health and others" [19].

The diversity of terminology relating to security is determined by the obvious amplification of cross-border implications of the contemporary crises, which are characterized by the surprising appearance and rapid, extensive and profound manifestations, propagating the major adverse effects on the stability of societal systems for a long time.

In this highly complex environment, the strategic decision-making, specific to national security, expresses with difficulty its anticipatory character and potential for effective coordination of preventive actions because it frequently involves taking many risks, configured by the insufficient relevant information on the forms of real manifestation of the possible defiances, challenges, dangers, threats and aggressions, a context that certainly increases the vulnerabilities of the state specialized structures, meant to preserve the fundamental national interests.

The studies on the defining elements of national security show many options: the inexistence of threats to the national values; the ability of a nation to protect its internal values in the context of the existence and proliferation of external threats; the creation of national and international conditions favorable to protecting the fundamental values of the state against any kind of threat; 
the promotion and defense of national interests, including the use of military force against dangers, threats or potential attacks, whatever their nature and forms of manifestation.

The depth analysis of the physiognomy of the contemporary international environment and of the determinations of its possible dynamics involves the study of national security as a macro system, simultaneously made with the detailed scientific investigation of its elements considered essential for the promotion and protection of state interests, vital for its existence.

"From the described perspective, national security is the regulatory, organizational, structural and functional framework for maintaining individual and collective security, protecting critical infrastructure and civil protection, ensuring or restoring public and constitutional order and defending the independence, sovereignty and territorial integrity of Romania” [20].

"Romania's national security means the state of legality, of social, economic and political balance and stability, necessary for the existence and development of the Romanian State as a sovereign, unitary, independent and indivisible state, for the maintenance of public order, as well as for the climate of unhampered exercise of the fundamental rights, freedoms and duties of citizens in accordance with the democratic principles and norms settled by the Constitution. [21]

"The protection of critical infrastructure is the national security component which consists of any activity that aims at ensuring the functionality, continuity and integrity of national and European critical infrastructures in order to deter, mitigate and neutralize a threat, risk or a vulnerable point" [22].

"Civil protection is a component of national security and is an integrating set of specific activities and organizational, technical, operational, humanitarian and public information tasks, planned, organized and carried out according to the law, to prevent and reduce the risks of disasters, their consequences and to provide protection for the population, property and the environment against the adverse effects of the emergency situations and armed conflicts and to rapidly remove their consequences and to ensure the conditions necessary for the survival of the affected persons" [23].

"Public order is the part of national security represented by the state of legality, social balance and peace corresponding to a socially acceptable level of compliance of law and civic conduct, which allows for the exercise of the fundamental rights and freedoms of man, as well as for the functioning of the state structures of law and is characterized by the credibility of the institutions, the health of morals, the normality in organizing and carrying on the political, social and economic life in accordance with the legal, ethical, moral, religious and any other norms, generally accepted by society" [24].

"Constitutional order is the part of national security which expresses the societal existential state conferred by the imperatives of the Romanian Constitution, necessary for the organization, coordination and uninterrupted functioning of the state institutions and for ensuring opportunities for exercising the fundamental rights, freedoms and duties of citizens in accordance with the general interests of the Romanian people" [25].

"National defense is the component of national security represented by the set of measures, actions and countermeasures carried out in the information, political, diplomatic, economic, financial, psychological, media, technological, intelligence, counterintelligence, administrative-territorial and armed conflict areas, undertaken nationally and internationally, in the context of an armed aggression against the country or if the state gets involved in a war with a view to achieving and perennially maintaining the sovereignty, independence, unity and territorial integrity of Romania" [26]. 
The national legal framework underlines the six defining elements of national security national security, critical infrastructure protection, civil protection, public order, constitutional order and national defense which give the institutions with strategic responsibilities in the field the prerequisites for the multidimensional study and the possibility of promoting concepts necessary to ensure the correlation between the fundamental, major and immediate interests of Romania as options for a harmonious and balanced development of society, and probable factors that can affect them.

"These imperatives have led to the institutionalization of the System of National Security - macro structure designed and operationalized to ensure the functioning of state bodies and the carrying out of socio-economic activities in a domestic and global environment characterized by tensional states, distortions and setbacks generating and proliferating crises of a diverse nature in the Romanian area of strategic interest" [27].

"The precise analysis of the dynamics and temporality of each critical possible situation which could affect the overall balance of the Romanian society is at the core on which the logic was based, being necessary for designing and producing complex networks intended for the harmonized management of the six key areas of national security, operationalized in accordance with the forecast scenarios, assumptions and actionable variants drawn up in advance so as to ensure the permanent functional balance of national security macro systems:

- the System of National Security Management - characterized by a high conceptual, organizational and functional privacy, was conducted in order to permanently supervise the evolution of the insecurity factors and timely warn the intervention forces within the other components of the System of National Security;

- the Management System of Critical Infrastructure Protection - conducted recently in a modern sense, due to the stringency of developing all social structures within the European Union in perfectly safe conditions. This complex set of specialized management is permanently made active and has the purpose of unitarily coordinating the efforts necessary to ensure the stable and efficient operation of systems, components or elements essential for the maintenance of vital societal functions, the health and safety of citizens, regardless of context;

- the Management System for Emergency Situations - conceived for the specialized management of the emergency situations and civil protection in an integrative framework;

- the Management System of Public Orderoperationalized for maintaining, ensuring and restoring public order, depending on the severity of the contexts in which the process of implementation of the norms of normal citizen cohabitation is affected, but particularly for managing the serious events involving the imposition of the emergency state, situation caused by the existence of imminent dangers to national security or the need to quickly remove the consequences of disasters;

- the Management System of Constitutional Order - alerted when the state of siege is established, situation in which it is mandatory that a set of exceptional political, military, economic, social or any other measures should be urgently adopted, which are meant to adapt the defense capacity of the country to the serious dangers directly threatening its sovereignty, independence, unity and territorial integrity;

- the National Defence Management System - operationalized in the unwanted existential context, but of the most serious gravity for the Romanian state, imposed by an armed aggression against it, or if the situation causes the declaration of the state of war" [28].

The successive transferring from a system of general management to another, of the responsibilities of integratively coordinating the supervision and action forces in the area 
of Romanian strategic interest (structures which, depending on the institution to which they belong, are organized and trained for a wide range of interventions) is achieved according to the likely development of the destabilizing vectors - defiances, challenges, dangers, threats and assaults - whose negative effects on the societal systems are hard to predict with a high degree of certainty.

The difficulty of this complex process can be amplified both by some organizationalfunctional deficiencies caused by social vulnerabilities and the lack of information relevant for planning and carrying out actions aimed at restoring the state of normality to the Romanian society - less frequent contexts, but which will involve taking the strategic decisional risk.

\section{Conclusions}

The diversity and depth of contemporary studies on the structure of national security and, in particular, of those that highlight the importance of each of its areas in the process of general social evolution reveals the strong attention paid to the strategic decision field for determining and promoting the action modalities destined to neutralize the possible influences produced by the factors of insecurity through reducing the Romanian state's vulnerabilities to these vectors generating instability.

In this respect, the contents of regulations specific to national security point to the obvious concern that in any situation requiring the firm and decisive implementation of their terms - contexts determined by possible gaps configured in the development of our society, the reaction or action potential of the System of National
Security should be employed, according to the amplitude and intensity of each type of manifested crisis.

The essential coordinate of the entire legislative set for the management of national security reveals the very clearly defined intention of inserting a variety of preventive measures and actions that directly manage any situation in which the Romanian society could find itself in, including the medium term very unlikely context when our country would face a crisis of maximum gravity - the political-military one.

"The contemporary security environment reflects significant changes in its evolution, including the obvious tendency of insecurity globalization determined both by the so powerful transnational interconnections and by the propagation, through resonance, of the crisis-generating factors that rapidly expand their negative influences in a veritable cascade of consequences which are very difficult to assess" [29].

The high degree of unpredictability of the undesired effects of defiances, challenges, dangers and threats on the possibilities of stagnation or even of involution of the whole societal ensemble determines the frequent reshaping and adaptation of the acting potential of the System of National Security to the real, concrete imperatives, specific to the Romanian society's development framework.

From this perspective, the complementarity of the action capabilities of its component subsystems must be a permanent feature, reflected in the operational plans of cumulative intervention and effective management of any type of social crisis.

References
[1] Gheorghe Udeanu, Managementul securităţii naţionale, Sibiu, Editura Academiei Forţelor Terestre "Nicolae Bălcescu", 2012, p. 2.

[2] Ibidem, p. 13.

[3] Vulnerable - that can be easily attacked, that has weak, faulty, criticable parts. Cf. Dicţionarului Explicativ al Limbii Române, Bucureşti, Editura Univers Enciclopedic Gold, 2009, p. 1209. 
[4] Defiance is, at the same time, challenge or ignorance, that is an ignorance that challenges, but also an attitude that ignores. Defiance is a directed, often threatening ignorance, Ibidem, p. 1012.

[5] Challenge means a series of gestures, realities or actions directed against someone in order to produce a reaction. Cf. ***, Criza, conflictul, războiul, vol. I, Bucureşti, Editura Universităţii Naţionale de Apărare „Carol I”, 2007, p. 19.

[6] Danger - situation, event that endangers or may endanger the existence, integrity of someone or something. Cf. Dicţionarul Explicativ al Limbii Române, Bucureşti, Editura Univers Enciclopedic Gold, 2009, p. 803.

[7] Threat - is a hostile action, with the purpose of deterring /.../ in the relations between states, the issues related to threat and its perception as such are very sensitive. Cf. ***, Criza, conflictul, războiul, vol. I, Bucureşti, Editura Universităţii Naţionale de Apărare „Carol I”, 2007, p. 19.

[8] Aggression - attack against a person or state. Cf. Dicţionarul Explicativ al Limbii Române, Bucureşti, Editura Univers Enciclopedic Gold, 2009, p. 22.

[9] Risk - possibility of getting into danger, of facing trouble or of incurring a loss. Ibidem, p. 957.

[10] Gheorghe Udeanu, op.cit, p. 52.

[11] Apud ***, Criza, conflictul, războiul, vol. I, Bucureşti, Editura Universităţii Naţionale de Apărare „Carol I”, 2007, p. 19.

[12] Gheorghe Udeanu, op.cit., pp. 55-56.

[13] Ibidem, p. 59.

[14] Ibidem, p. 56.

[15] ***, Criza, conflictul, războiul, vol. I, Bucureşti, Editura Universităţii Naţionale de Apărare „Carol I”, 2007, p. 122.

[16] Gheorghe Udeanu, op.cit., p. 57.

[17] Ibidem, p. 58.

[18] Ibidem.

[19] Ibidem, p. 13.

[20] Ibidem, p. 14.

[21] Legea $n r$. 51, din 8 iulie 1991, privind siguranţa naţională a României, publicată în Monitorul Oficial nr. 163, din 07 august 1991, art. 1.

[22] Ordonanţa de urgenţă a Guvernului României nr. 98, din 3 noiembrie 2010, privind protecţia infrastructurilor critice, publicată în Monitorul Oficial al României nr. 757, din 12 noiembrie 2010, art. 3 , lit. c).

[23] Legea $n r .481$, din 8 noiembrie 2004, privind protecţia civilă, publicată în Monitorul Oficial nr. 1.094, din 24 noiembrie 2004, art. 1, alin. (1).

[24] Hotărârea Guvernului României nr. 1040, din 13 octombrie 2010, pentru aprobarea Strategiei de ordine publică 2010-2013, publicată în Monitorul Oficial nr. 721, din 28 octombrie 2010, Index de termeni, 1.

[25] Gheorghe Udeanu, op.cit., p. 57.

[26] Ibidem.

[27] Ibidem.

[28] Ibidem, pp. 11-12.

[29] Ibidem, p. 36. 